\title{
TRAMWAY MANAGEMENT SYSTEM IN INDONESIA
}

\author{
Melia Damayanti \\ Directorate General of Railway, Ministry of Transportation, Jakarta Pusat, INDONESIA \\ meliabtpjateng@gmail.com \\ Siti Malkhamah \\ Civil and Environmental Engineering Department, Universitas Gadjah Mada, Yogyakarta, INDONESIA \\ smalkhamah@mstt.ugm.ac.id \\ Karen Walker \\ IT Solution, Boots SAP Center of Expertise, London, UK \\ karenwalker987@gmail.com
}

\begin{abstract}
Tramway systems, which can carry more passengers than buses at one haul, are now being proposed to meet Indonesia's public transport requirement. The objective of this research is to analyze the management structures for operating tram in different countries and then propose a suitable organizational structure for operating trams, if re-introduced, in Indonesia. The author chose France (Montpellier tramway), Germany (Karlsruhe tram-train) and the UK (Nottingham Express Transit) as the role model countries for investigation. From the analysis, the most appropriate organizational structure and suitable tramway management structure for operating tramways implementation in Indonesia. The key features of the research are to establish public transport company by local government to manage all public transport systems, propose tramway construction and operation to exist as separate departments under the tramway team division of the public company, recommend the public transport company to have responsibility for overseeing construction of the trams, operating, and maintaining the trams, suggest local government to own them and have responsibility for tramway strategic policy, control regulation as well as supervision and coordination of the performance of the public transport company, propose joint working between public and private sectors.
\end{abstract}

Keywords: Tramway, Tramway System, Management System, Organization Structure

\section{INTRODUCTION}

Tram are likely to be selected as the preferred option in order to provide a reliability public transport in Indonesia. For planning and designing tramways system in Indonesia, it needs to learn from successful experiences of other countries.

The overall objective of this research is to identify the most suitable management structures to operate tram systems for the probable future tram operations in Indonesia. In order to do this, the research aims to:identify different organizational models for tram management systems of three selected countries, analyze these different models in terms of operating and construction management structure, funding, performance and profitability, consider how another developing country has developed its tramway management system and evaluate the different models in the context of Indonesia in general and hence recommend the most suitable management structure option for future Indonesian tramway systems.
In this research, the management organizational structure includes who is responsible for tram system strategy and policies, who constructs the tram, who owns the tram, who maintains the tram, who operates the tram service, who is funding the tramway systems as well as who controls and regulates the tramway system. This research concerns to management structures for the ongoing operation of tram systems, but the organizational models for tramway construction are also included. The resources used to study comparisons of different organization structures are based on tram in Montpellier-France, KarlsruheGermany, and Nottingham-UK. The indicators in choosing the best organization structure are based on relevant performance indicators as well as profitability (ratio of fare revenue to operational and administrative costs).

\section{TRAMWAY SYSTEM}

From the 1800's until the middle of the 1900's, tramway systems operated in several big cities in Indonesia such 
as Batavia (now Jakarta), Surabaya, Semarang, and Surakarta. Currently, there are several types of public transport available in several big cities in Indonesia such as BRT, local bus, taxi, angkuta and ojek (motorcycle taxi). The following are several statements from the Indonesian government that support the implementation of tramway systems in Indonesia.

a) One of the visions for Indonesian Railway by 2030 as stated in the Indonesian Railway National Master Plan is to have the railway based transportation as the backbone of mass transport in cities/urban areas, especially in Jakarta, Bandung, Surabaya, Medan, Yogyakarta, Palembang, and Semarang (Directorate General of Railway, Ministry of Transportation of Indonesia, 2010)

b) The type of railway that can be implemented in Indonesia as stated in Law No.23/2007 Chapter III section 4 about Railways is to have the type of railways that are Normal Speed Railway, HighSpeed Railway, Monorail, Linear induction motor railway, Air motion railway, Magnetic levitation railway, Tram, and Cable car.

Surabaya is the city in Indonesia which is currently attempting to reintroduce a tramway in Indonesia. There is so many support and against Surabaya, tramway system had been planned. Generally, the people who are less supportive have doubts about the very high value of the investment (Hadi, 2014).

\section{TRANSPORTATION MANAGEMENT SYSTEM}

Transportation system management is the process of coordinating the many different services and functions that are part of a transportation system (Meyer, 2003).

\subsection{Management System of Tramway in Montpellier,} France

SMTU (Societe Montpellieraine des Transport Urban) is the public transport company in Montpellier. One of the SMTU tasks was to invite tenders for the management of the construction of the tramline in Montpellier. Since 2001, the SMTU has changed its name into the TaM (Transports de l'agglomération de Montpellier), which has a responsibility to provide a reliable public transport. $\mathrm{TaM}$ also provides a very good integration of transport modes in Montpellier (Montpellier Now Team, 2014)

\subsection{Management System of Karlsruhe Tram - Train, Germany}

In Germany, there are three levels of public transport management systems. At the strategic level, there are associated partners which together have political responsibility establishing guidelines for the development and performance of public transport. At the administration level, Karlsruhe Verkehrsverbund $\mathrm{GmbH}$ (KVV) is has a responsibility to manages public transport contracts and integration with other public transport systems. At the operational level, the public transport companies are responsible for the performance of the railway, tram, bus and other public transportation services (Wagensommer, 2014).

\subsection{Management System of Nottingham Express Transit - United Kingdom}

In Phase 2, Tramlink Nottingham Ltd. (a private company) was appointed as the preferred bidder and was awarded a contract under a concession agreement to develop an extension to the city's tram service (Therry, 2014). The Tram link Nottingham consortium signed two main contracts which have tight interface agreement with Nottingham Trams Ltd for design and construction, and with Taylor Wodroow - Alstom joint venture for operation and maintenance.

\section{METHODOLOGY}

The information was collected from the literature related to tram operations and interviews with experts in some tramway companies. The gained information is the data about management organization structure in several tramway companies, and also their performance and profitability. The performance indicators used in the evaluations of the different management models are calculated by analyzing characteristics of the tram systems, such as length, the number of lines, the number of stops, the average distance between stops, and passengers' trips per year, the number of vehicles, vehicle capacity and dwell time (s). The profitability is derived from the calculation of the ratio between fare box revenue and operational and administrative cost. Finally, the most crucial stage is to analyze options and make some recommendations about the most suitable management organization structure for Indonesian tramways. 


\section{RESULTS AND DISCUSSIONS}

\subsection{Identification for Tramway Management System Organization Models}

Table 1 shows the comparison of Montpellier, Karlsruhe, and Nottingham Tramway.

Table 1. The comparison of Montpellier, Karlsruhe, and Nottingham Tramway (Montpellier Now Team, 2014; Therry, 2014; Wagensomer, 2014)

\begin{tabular}{|c|c|c|c|c|}
\hline \multirow[t]{2}{*}{ No. } & \multirow[t]{2}{*}{ Items } & \multicolumn{3}{|c|}{ Tramway / Tram-train Systems } \\
\hline & & Montpellier & Karlsruhe & Nottingham \\
\hline 1. & $\begin{array}{l}\text { Responsibility for } \\
\text { operating the tramway }\end{array}$ & $\begin{array}{l}\text { Public } \\
\text { Companies }\end{array}$ & Public Companies & Private Companies \\
\hline 2. & $\begin{array}{l}\text { Private sector } \\
\text { contribution to project }\end{array}$ & Less & Less & More \\
\hline 3. & Local collaboration & $\begin{array}{l}\text { Not much } \\
\text { collaboration }\end{array}$ & $\begin{array}{l}\text { Much collaboration } \\
\text { between districts }\end{array}$ & $\begin{array}{l}\text { Not much collaboration between } \\
\text { districts }\end{array}$ \\
\hline 4. & Making operational & Easier & Easier & Not so easy \\
\hline 5. & Ownership of the trams & Local government & Local government & Local government \\
\hline 6. & $\begin{array}{l}\text { Responsibility for } \\
\text { maintaining the trams }\end{array}$ & $\begin{array}{l}\text { Public } \\
\text { companies }\end{array}$ & Public companies & Sub-Contract with private companies \\
\hline 7. & $\begin{array}{l}\text { Integration with other } \\
\text { transport modes, } \\
\text { including ticketing }\end{array}$ & Integrated & Integrated & Less Integrated \\
\hline 8. & $\begin{array}{l}\text { The initial project } \\
\text { appraisal process }\end{array}$ & Good & Time Consuming & Time Consuming \\
\hline 9. & The funding process & Good & Good & A bit longer \\
\hline 10. & $\begin{array}{l}\text { The majority capital } \\
\text { funding sources }\end{array}$ & $\begin{array}{l}\text { Local } \\
\text { Government }\end{array}$ & Central Government & $\begin{array}{l}\text { Private Sector Repaid over } 30 \text { year } \\
\text { period mainly by central government }\end{array}$ \\
\hline 11. & $\begin{array}{l}\text { Main way for collecting } \\
\text { the capital funding }\end{array}$ & $\begin{array}{l}\text { Versement transport } \\
\text { policy }\end{array}$ & $\begin{array}{l}\text { Communal transport } \\
\text { investment program }\end{array}$ & $\begin{array}{l}\text { Private Finance } \\
\text { Initiative }\end{array}$ \\
\hline 12. & Operating Funding & Fare box revenue & Fare box revenue & $\begin{array}{l}\text { The Authority funds the operating } \\
\text { company via a "fixed" fee, with the fare } \\
\text { revenue being held by the authority }\end{array}$ \\
\hline 13. & Fare box ratio & $\begin{array}{l}\text { Exceeds the } \\
\text { operating cost }\end{array}$ & $\begin{array}{l}\text { Exceeds the } \\
\text { operating cost }\end{array}$ & Less than operating cost \\
\hline 14. & $\begin{array}{l}\text { Segregation level with } \\
\text { road traffic }\end{array}$ & $>90 \%$ & $80 \%$ & $63 \%$ \\
\hline 15. & Daily Passengers/station & 1799 & 2682 & 1191 \\
\hline 16. & Daily Passengers $/ \mathrm{km}$ & 3096 & 1942 & 1826 \\
\hline 17. & Daily Passengers/vehicle & 2218 & 1945 & 1826 \\
\hline
\end{tabular}




\subsection{Reintroducing Indonesian Tramways}

It is important to recognize certain key differences between the public transport situation in Indonesia and the European cities, as well to assess the impact of these differences when devising organizational structures for Indonesia. The key differences can be seen in Table 2.

Table 2. The New Requirement of Indonesian Tramway

\begin{tabular}{l} 
No. $\begin{array}{l}\text { The differences between Indonesia cities condition } \\
\text { and Montpellier, Karlsruhe \& Nottingham }\end{array}$ \\
\hline 1. \\
$\begin{array}{l}\text { The current lack of awareness of most Indonesian } \\
\text { people about what the tram is. }\end{array}$ \\
2. The very fast increase in private vehicle growth in \\
Indonesia, especially motorcycles, due to the very \\
cheap motorcycle operating cost. This condition makes \\
it difficult for public transport to compete with private \\
cars and motorcycles.
\end{tabular}

3. The economic situation differences between Indonesia The tramway system must be less dependent on the and the three countries due to Indonesia being a government in funding both capital cost and operating

The huge socialization program to the citizen before implementation

The tariff of the tramway should be very low developing country

4. The domestic component priority of Indonesian government policy

cost

Improving local expertise via partnerships between Indonesian private companies and expert foreign companies

5. A lack of safety awareness and less discipline of the most road users in Indonesia

Very strict regulation of safety including both in segregated rights of way or in mixed traffic

6. No special provision for disabled people and elderly people using public transport in Indonesia

Must be considerations about facilities and access for disabled and elderly people

7. Unavailability of clear passenger information systems in most road public transport in Indonesia

Provide reliable passenger information system both outboard and onboard

8. Unreliable time scheduling in most road public Provide reliable time scheduling and ensure transport in Indonesia

9. Non-integrated passenger ticketing system in Indonesia

10. Some Indonesian people still unfamiliar with IT (Information Technology) especially elderly people

11. Lack of inter-mode access including access between pedestrians and transport mode

12. Indonesia is country that has a very high of rainfall

13. Indonesia's population is very dense in some major cities in Indonesia with an enormous number of road users which makes the road seem crowded and full of safety risks

14. Geographically, many cities in Indonesia consist of a lot of hills and mountains, sometimes the difference in altitude between urban and rural locations is quite high and at the present time, the transportation system connecting urban and rural areas is still unreliable. infrastructure design and traffic controls support reliable services

Provide integrated passenger ticketing system

Provide information system and ticketing system both manually and digitally

Provide reliable inter-mode access including access to pedestrians and other transport modes (fully integrated transport mode)

Provide a good design of tram stops or stations so that the passenger is comfortable waiting for the next tram

Special design of trams, for example, they must have a very good braking system and also special design of infrastructure/tram-track

Some of the Indonesian cities need a tram-train to connect urban and rural areas. But this will need a lot of capital cost, for example, to build so much new infrastructure. So there must be consideration of so many aspects depending on the city itself when choosing a tramway or tram-train. However whatever the type, tram initiatives can be proposed with the same management organization structure and funding planning 
The following are the considerations taken into account in developing Indonesian tramway management system as depicted in Figure 1.

a) The need to transport as many passengers as possible with affordable fares, safely and comfortably so that road users become interested in using the tramway and leave private cars/motorcycles

b) The management of the Nottingham tramway system which involves many sub-contractors is in line with the domestic priority of Indonesian government policy

c) There are several parts of the management system in the Montpellier tramway that might be appropriate to be implemented in Indonesia

d) At the present time, there is no integrated ticketing system provided in Indonesian Public transportation systems. Therefore, management that supports the integration system will be very useful

e) Indonesia is a country that still has a complexity problem in bureaucracy. By learning from the other countries such as France in the appraisal and funding process, this will help the process to be less time consuming

f) Indonesia is a developing country which has to cover multiple national needs with a limited budget. Therefore, it will be wiser if Indonesian tramway up-front capital funding is planned with as little as possible dependency on the government, both local and central. The involvement of the private sector in raising capital funding will be very useful and can reduce the up-front government burden

g) The fare box ratio level is very important to guarantee the sustainability of tramway operation. On the other hand, Indonesian tramways need to have a very low tariff to attract the ridership and compete with the cheapness of motorcycles, so that the intervention of local government cannot be avoided.

h) It is likely that tramways in Indonesia will have more on-street running mixed with other traffic than segregated. This will require the management to give information and socialization.

There are various options for resourcing the up-front capital funding among others: direct borrowing from banks to the public transport company, equity invested in the public transport company, financing by the companies contracted to provide the construction and operation services (paid back over an agreed time), External/foreign government financing/lending, subsidies both local and central government. For operating funding, besides fare box revenue there are several possibilities that can be adopted such as adoption of a policy similar to Versement Transport in France and advertisement program.

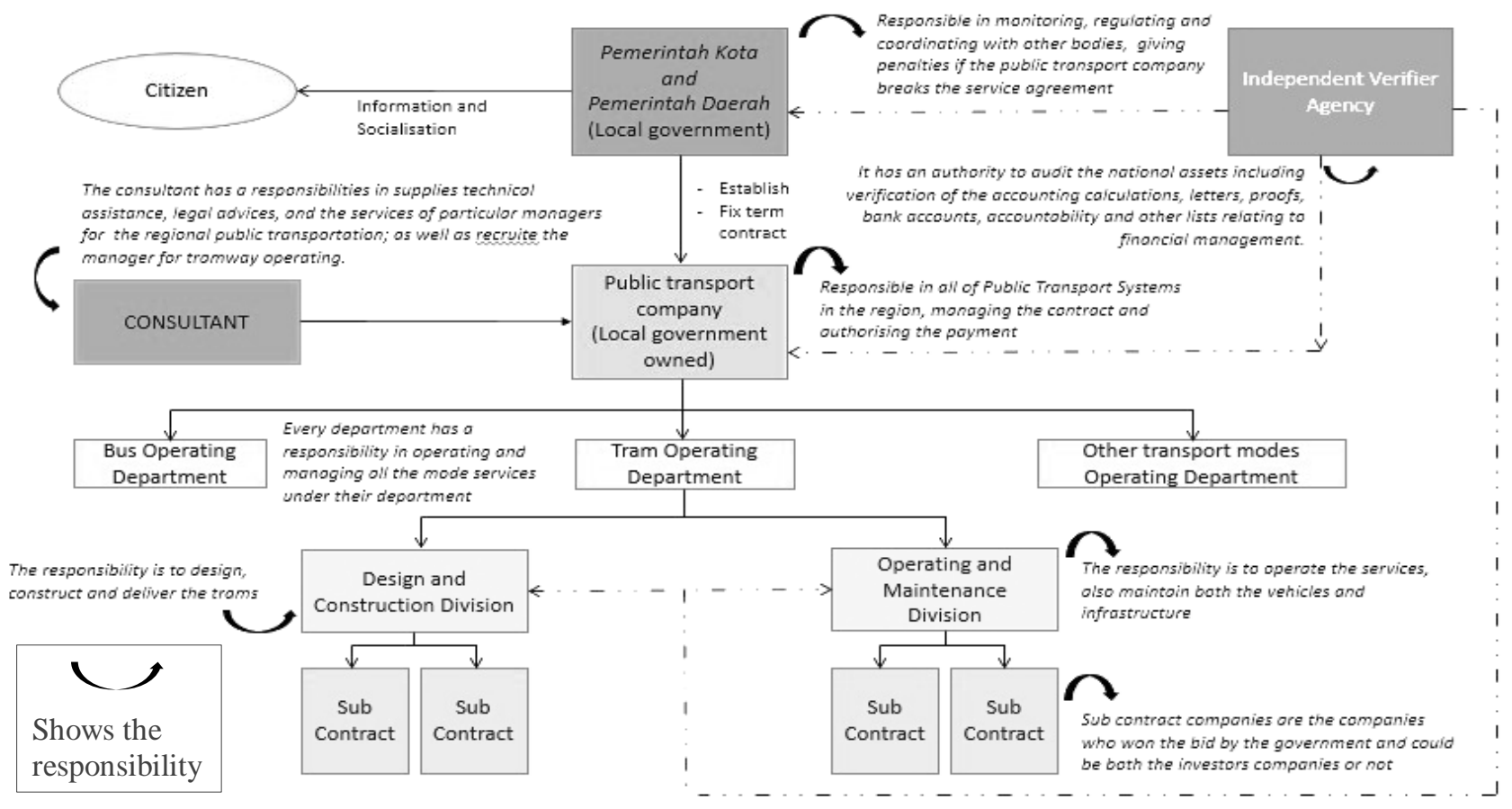

Figure 1. Structure for tramway management in Indonesia. 


\section{CONCLUSIONS AND RECOMMENDATIONS}

\subsection{Conclusions}

From the results, it can be summarized that:

a) Integration between tramways and other modes should provide convenience for public transport users to attracting more passengers

b) Attracting many passengers is one of the Indonesian tramway's objectives, and without a good management structure this achievement could not have been achieved

c) Tram-train type of transport can be selected in several big cities in Indonesia. But implementation of tram-train must be considering of possibility of very high costs requirement

d) Willingness to pay for traveling by public transport in Indonesia is very low due to its rival, motorcycles

e) Indonesian tramways should ideally be sustainably self-funding but besides that, the tariff should be very low

f) Less experience of tramways in Indonesia means that Indonesia should learn from the other countries' successful experiences, but in addition should adapt to the situation, condition and local requirements in Indonesia.

\subsection{Recommendations}

There are some recommendations which may be carried out in the future research, i.e.:

a) Establishment of a public transport company by local government to manage all public transport systems in a particular area

b) Tramway construction and operation to exist as separate departments under the tramway team division of the public company

c) The public transport company to have responsibility for overseeing construction of the trams, operating the tram service, maintaining the tram infrastructure and vehicles, managing contracts and authorizing payments Local government to have responsibility for tramway strategic policy, control and regulation as well as supervision and coordination of the performance of the public transport company and also to own the tram

d) Joint working between public and private sectors to help develop local expertise (local private tramway companies)

e) A massive program of information and socialization by local government.

\section{REFERENCES}

Directorate General of Railway, Ministry of Transportation of Indonesia, 2010. Rencana Induk Perkeretaapian Nasional, [National Main Plan of Railway], Jakarta: Ministry of Transportation of Indonesia.

Hadi, 2014. Jawa Pos.co.id. [Online] Available at: http://www.skyscrapercity.com/showthread.php

Meyer, M. D., 2003. Transportation System Organization, Management, and Interoperability. In: Sustainable Built Environment, p. 3.

Montpellier Now Team, 2014. By Tram. [Online] Available at: http://www.ot-montpellier.fr/en/bytramway

Therry, P., 2014. Nottingham Express Transit [Interview] (6 June 2014).

Wagensommer, H., 2014. Karlsruhe Tram-train [Interview] (22 May 2014). 